Med Princ Pract 2015;24:99-100

DOI: $10.1159 / 000365743$

\title{
Subclinical Hypothyroidism: To Treat or Not to Treat?
}

\author{
Min Li, Zhenyu Tang \\ Department of Neurology, Second Affiliated Hospital of \\ Nanchang University, Nanchang, China
}

\section{Dear Editor}

Subclinical hypothyroidism refers to subjects who have elevated serum thyroid-stimulating hormone levels and whose serum thyroid hormone levels are within the normal reference range. The prevalence of subclinical hypothyroidism in the US population was about $4.3 \%$ in NHANES III, and the overall prevalence has been reported to range from 4 to $20 \%$ in the general adult population $[1,2]$. It is reportedly higher in women aged more than 60 years $[3,4]$. Screening and treatment of subclinical hypothyroidism should thus clearly be a public health priority.

Over the past several decades, based on a strong body of evidence, it has been postulated that subclinical hypothyroidism is associated with cardiovascular risk factors (such as cholesterol levels, systolic blood pressure, and atherosclerosis) [5-7]. Since the late 1980s, subclinical hypothyroidism has been the major focus of numerous clinical and autopsy studies on cardiovascular disease, particularly coronary heart disease (CHD) $[8,9]$. Although data on the relationship between subclinical hypothyroidism and $\mathrm{CHD}$ events or mortality were supported in systematic reviews and quantified in meta-analyses of prospective studies [10-13], not all studies have shown that subclinical hypothyroidism affects risk factors for CHD and cardiovascular and all-cause mortality.

In 2006, Rodondi et al. [10] reported that subclinical hypothyroidism was associated with an increased risk of CHD. This finding was consistent with another previous meta-analysis of Singh et al. [12]. In addition, Singh et al. [12] suggested that mortality from cardiovascular causes, rather than all-cause mortality, was significantly higher at follow-up. However, a meta-analysis including 10 cohort studies from Ochs et al. [13] found that subclinical hypothyroidism may be associated with a modest increased risk for CHD and mortality. Additionally, Völzke et al. [11] suggested that the currently available evidence for a causal relation of hypothyroidism with mortality was weak and should particularly not be used to decide whether patients with subclinical hypothyroidism should be treated.

\section{KARGER 125\%}

E-Mail karger@karger.com www.karger.com/mpp
(C) 2014 S. Karger AG, Basel 1011-7571/14/0241-0099\$39.50/0

Karger Open access

This is an Open Access article licensed under the terms of the Creative Commons Attribution-NonCommercial 3.0 Unported license (CC BY-NC) (www.karger.com/OA-license), applicable to the online version of the article only. Distribution permitted for non-commercial purposes only.
Recently, in the 16th European Congress of Endocrinology, Andersen et al. [14] reported that levothyroxine is not associated with lower all-cause mortality in patients with subclinical hypothyroidism. Controversy persists about whether screening for and treatment of subclinical hypothyroidism are warranted because the current evidence regarding incidence and mortality is inconsistent, and it is imperative to explore the subsequent concerns. First of all, it is necessary to further summarize higher-quality prospective evidence about the relationship between subclinical hypothyroidism and CHD and cardiovascular or all-cause mortality; it plays a key role in the prevention of CHD incidence and mortality. Secondly, treatment of adults with subclinical hypothyroidism with regard to $\mathrm{CHD}$ or mortality should be studied in randomized, placebo-controlled trials to assess the benefits of antithyroid medications. Thirdly, taking into account the untreated individuals, there is a trend toward an increased incidence and mortality; preferably randomized controlled studies on the treatment of subclinical hypothyroidism should have a longer follow-up time.

In summary, regarding whether or not patients with subclinical hypothyroidism require intervention, the following recommendations should be considered: (a) large prospective studies or more comprehensive estimates are necessary to clarify the risk of $\mathrm{CHD}$ or mortality in patients with subclinical hypothyroidism, (b) longterm randomized controlled studies are needed to assess the importance of treating patients with subclinical hypothyroidism, and (c) prospective studies could explore whether or not the treatment of subclinical hypothyroidism could improve its adverse health outcomes.

\section{References}

1 Cooper DS, Biondi B: Subclinical thyroid disease. Lancet 2012;379:11421154.

- 2 Hollowell JG, Staehling NW, Flanders WD, et al: Serum TSH, T(4), and thyroid antibodies in the United States population (1988 to 1994): National Health and Nutrition Examination Survey (NHANES III). J Clin Endocrinol Metab 2002;87:489-499.

-3 Sawin CT, Castelli WP, Hershman JM, et al: The aging thyroid: thyroid deficiency in the Framingham Study. Arch Intern Med 1985;145:13861388

4 Surks MI, Ortiz E, Daniels GH, et al: Subclinical thyroid disease: scientific review and guidelines for diagnosis and management. JAMA 2004; 291:228-238.

5 Althaus BU, Staub JJ, Ryff-De LA, et al: LDL/HDL-changes in subclinical hypothyroidism: possible risk factors for coronary heart disease. Clin Endocrinol (Oxf) 1988;28:157-163.

6 6 Ye Y, Xie H, Zeng Y, et al: Association between subclinical hypothyroidism and blood pressure - a meta-analysis of observational studies. Endocr Pract 2014;20:150-158.

\section{Zhenyu Tang}

Department of Neurology, Second Affiliated Hospital of Nanchang University No. 1, Minde Road

Nanchang, Jiangxi 330006 (China)

E-Mail zytang07016@sina.com 
7 Hak AE, Pols HA, Visser TJ, et al: Subclinical hypothyroidism is an independent risk factor for atherosclerosis and myocardial infarction in elderly women: the Rotterdam Study. Ann Intern Med 2000;132:270 278.

$>8$ Rodondi N, Newman AB, Vittinghoff E, et al: Subclinical hypothyroidism and the risk of heart failure, other cardiovascular events, and death. Arch Intern Med 2005;165:2460-2466.

>9 Imaizumi M, Akahoshi M, Ichimaru S, et al: Risk for ischemic heart disease and all-cause mortality in subclinical hypothyroidism. J Clin Endocrinol Metab 2004;89:3365-3370.

$\checkmark 10$ Rodondi N, Aujesky D, Vittinghoff E, et al: Subclinical hypothyroidism and the risk of coronary heart disease: a meta-analysis. Am J Med 2006; 119:541-551.
11 Völzke H, Schwahn C, Wallaschofski H, et al: Review: the association of thyroid dysfunction with all-cause and circulatory mortality - is there a causal relationship? J Clin Endocrinol Metab 2007;92:2421-2429.

12 Singh S, Duggal J, Molnar J, et al: Impact of subclinical thyroid disorders on coronary heart disease, cardiovascular and all-cause mortality: a meta-analysis. Int J Cardiol 2008;125:41-48.

13 Ochs N, Auer R, Bauer DC, et al: Meta-analysis: subclinical thyroid dysfunction and the risk for coronary heart disease and mortality. Ann Intern Med 2008; 148:832-845.

14 Andersen MN, Olsen AS, Madsen JC, et al: Levothyroxine substitution in subclinical hypothyroidism: does it have a beneficial effect on all-cause mortality? Endocr Abstr 2014, DOI: 10.1530/endoabs.35.OC1.2. 